\title{
画素内環境資源情報の抽出
}

—NOAA/AVHRR データによる積雪領域抽出の事例研究—

\section{Extraction of Environment and Resources Information inside a Pixel - A Case Study for Snow Covered Area Extraction from NOAA/AVHRR Data-}

\section{1.はじめに}

画素内推定は, 古くて新しい命題として多く研究さ れているが，ここでは画素内の占有率が比較的容易に 抽出できて，しかも実用的価値の高い分野として NOAA-AVHRR デー夕による積雪領域の画素内抽出 についての研究事例を紹介する。

\section{2. 積雪領域における画素内解析}

リモートセンシングデータを用いて積雪領域の最新 状態の情報抽出は，領域における融雪量や，流出量を 推定し，水資源量の推定に，有意義なデー夕を提出す ることが，期待されている。しかしながら，これらの 情報を実際に地球観測衛星から収集さる際には天候障 害が問題となる。特に融雪期には不順な天候が続くこ とが多い。

LANDSAT，MOS-1などの地球観測衛星の観測周 期は，16日に 1 回である。このため，融雪期の衛星観 測日が好天に恵まれる確率は低い。しかしデータが好 天で入手できれば，地上分解能が30～ $50 \mathrm{~m}$ 程度である ため，尾根と谷が分離して確認でき，積雪領域を解析 するには十分な精度を有している。

いっぽう気象衛星 NOAAのAVHRR (Advanced Very High Resolution Radiometer) デー夕は，毎日 2 回の観測をおこなっているので，晴れ間をぬっての

*(侏)エア・グラフ

$* *$ 本解説は, 1990年 9 月に土木学会に投稿済の論文原稿 の一部を抜粋し，修正を加えたものである。

「写真測量とリモートセンシング」Vol. 30, No. 4, 1991

\author{
力 丸 厚* \\ Atsushi RIKIMARU
}

デー夕収集の可能性が高い。ところが, NOAA デー夕 の地上空間分解能は, 最も条件が良い軌道直下点 (Nadir) でも $1 \mathrm{~km}$ 程度である。このため日本の地形 規模では，尾根と谷の空間的な分離が困難な場所が多 く, 好天のデー夕は入手できても解析は容易ではない。 そこで, 両者の長所を生かして, 工学的な可能性を 求める手法を検討した。つまり, 気象衛星の特徴であ る即時性があり空間的に粗いデー夕と, 過去の好天時 に観測された高い地上分解能の地球観測衛星のデータ を組み合わせて，気象衛星の「画素内情報」を推定が できないだろうかということである。

具体的には，モニタリングを目的とするNOAA データ 1 画素 (約 $1 \mathrm{~km}$ 四方程度) の内部の状態を, マ クロピクセルモデルという画素内推定手法と, 過去の 融雪期の好天日の LANDSATデータを用いて推定し ようとするものである。

手順としては，大きく分けて以下の 2 段階となる。

(1) NOAA-AVHRR デー夕を用い，画素内の積雪 領域の占有率をマクロピクセルモデルというモデルを 用いて推定する。この段階では, 画素内の積雪占有率 は推定できるが，画素内の積雪位置は不明である。

(2) 算出された画素内のどの位置に雪が存在するか を, 過去の MSS データを, 融雪段階の異なる複数個組 み合わせることで, 1 画素内で「より融けやすい領域」 と，「より融け難い領域」を序列化することにより，「融 雪の履歴」をモデル化し, NOAA-AVHRR デー夕の 画素内積雪領域の位置を推定する。

\section{3 画素内の積雪占有率の推定方法}

（1）積雪・非積雪教師領域の抽出

データの前準備としてNOAA・AVHRR データか 
ら対象地区を切り出し, 緯経度に対応するように画像 データの幾何補正を実施する。また, MSS デー夕に関 しても同様に幾何補正を実行し，NOAA データと MSSデー夕が対応できる画素配列にする。NOAA デー夕 1 画素内が MSS データ $20 \times 20$ 画素に分割対応 するように調整する。

積雪領域を解析するには，まず積雪・非積雪領域と して典型的である地区を教師データとして，的確に抽 出することが必要である。マルチスペクトル画像デー タ中から, 積雪領域を判別して, 安定した精度で積雪. 非積雪領域の教師を抽出する方法として, 相乗平均に よる積雪判別指標； I snow を設定し，積雪領域の教 師抽出として用いる。積雪領域は, 肉眼では白色に見 える。これは，分光特性に置き換えて考えると，各波 長帯域とも分光反射率が高く, 波長に関して平坦な特 性を有している。この特性は, ラジオスペクトルメー 夕による測定で, 可視・近赤外光において確認されて いる。雪面のこのような特性を強調するバンド間演算 として, バンド間の相乗平均を採用し, 樍雪領域らし さの指標としたものである。

積雪判別指標は, NOAA の場合 I nsnow, LANDSATの場合 I lsnow とを，それぞれ以下の式(1), 式(2) によって求めた。

NOAA AVHRR 積雪判別指標

I nsnow $=(\mathrm{B} 1 \times \mathrm{B} 2)^{1 / 2}$

LANDSAT MSS 積雪判別指標

I 1 snow $=(B 4 \times B 5 \times B 7)^{1 / 3}$

用いた波長带域は NOAA AVHRRの場合 B1： BAND-1可視光および B2：BAND-2近赤外線の 2 つ

表一 1 NOOAAVHRR センサの仕様

\begin{tabular}{clll}
\hline Band & 分解能 & 検知器 & 波長域 $\mu \mathrm{m}$ \\
\hline 1 & $1.1 \mathrm{~km}$ & Silicon & $0.58-0.68$ \\
2 & $1.1 \mathrm{~km}$ & Silicon & $0.725-1.10$ \\
3 & $1.1 \mathrm{~km}$ & InSb & $3.55-3.93$ \\
4 & $1.1 \mathrm{~km}$ & HgCdTe & $10.3-11.3$ \\
5 & $1.1 \mathrm{~km}$ & HgCdTe & $11.5-12.5$ \\
\hline
\end{tabular}

\section{表ー2 LANDSAT MSS センサの仕様}

\begin{tabular}{cccc}
\hline Band & 分解能 & 検知器 & 波長域 $\mu \mathrm{m}$ \\
\hline 4 & $57 \mathrm{~m}$ & Silicon & $0.50-0.60$ \\
5 & $57 \mathrm{~m}$ & Silicon & $0.60-0.70$ \\
6 & $57 \mathrm{~m}$ & Silicon & $0.70-0.80$ \\
7 & $57 \mathrm{~m}$ & Silicon & $0.80-1.10$ \\
\hline
\end{tabular}

の領域である。また, LANDSAT MSSの場合 B4： BAND-4可視緑色光, B5:BAND-5可視赤色光, B7 : BAND-7近赤外線の 3 領域である。また，両センサの 波長带域等は，表一1，2に示している。

いっぽう，非積雪領域の場合においても，積雪判別 指標の低域部分を用いることで，抽出が可能である。 しかし，低域部分は，地上の土地被覆状態に依存して， 多岐にわたった分光特性集合となり，ヒストグラムを 調べても，非積雪領域としての，しきい值を決定する のが, なかなか難しい。そこで, 実際の画像を人間が モニタして典型的非積雪領域を，会話的に指定して抽 出した。

\section{（2）積雪・非積雪領域の判別基準}

画像データ中の任意の地点が, 教師領域に比較して 積雪領域か非積雪領域かを判別するために，図 1 に示

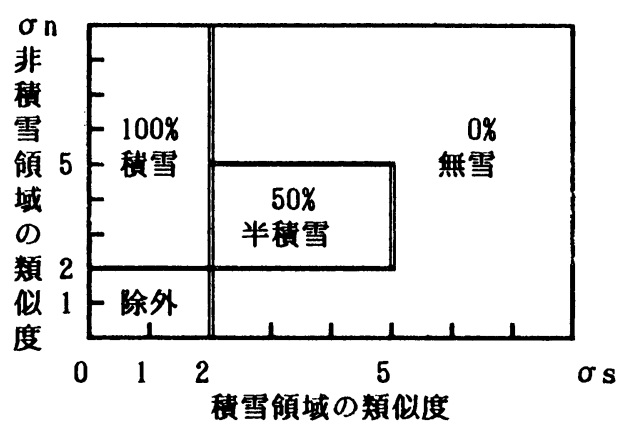

図-1 積雪・無積雪の判別基準

す判別図を設定した。積雪領域の教師デー夕（積雪判 別指標）の平均值からの距離を標準偏差 $\sigma \mathrm{s}$ を単位に して横軸にとり，同様にして非積雪領域の教師データ の平均值からの距離を標準偏差単位 $\sigma \mathrm{n}$ で縦軸にとっ た。

各軸は各々 1 次元の類似度を示していると考えるこ とができる。教師データが正規分布をしていたとする ならば，平均値士 $2 \sigma$ の区間には測定值の $95.4 \%$ が分 布すると考えられる。そこで, 積雪領域の $|\sigma \mathrm{s}| \leqq 2.0$ の区間を積雪 $100 \%$ の間とみなすこととした。一方， 非積雪領域 $|\sigma \mathrm{n}| \leqq 2.0$ の区間は積雪 $0 \%$ の領域とみ なすことができる。ところで,

| $\sigma \mathrm{s}|\leqq 2.0 \mathrm{AND}| \sigma \mathrm{n} \mid \leqq 2.00$ 区間は，積雪であり 非積雪であるということとなり，内容的に矛盾を生じ る。そこで, 本研究では, 解析から除外することとし 
た。なお，実際の適用例では，この条件に当てはまる

データは, 存在しなかった。

$2.0<|\sigma \mathrm{s}| \leqq 5.0$ AND $2.0<|\sigma \mathrm{n}| \leqq 5.0$ の区間は,

積雪・非積雪の両状態から, 遠からず近からずの距離

にあると考えられる。そこで, 灰色状態の領域として

半積雪領域として設定し， $50 \%$ の積雪領域とした。上
記以外の区間で

$|\sigma \mathrm{s}| \leqq 5.0 \mathrm{AND}|\sigma \mathrm{n}| \leqq 5.0$ の地点を, 非積雪領域 と判別した。

（3）マクロピクセルモデルの積雪領域への適用法

積雪領域における画素内推定は, 市街地における土

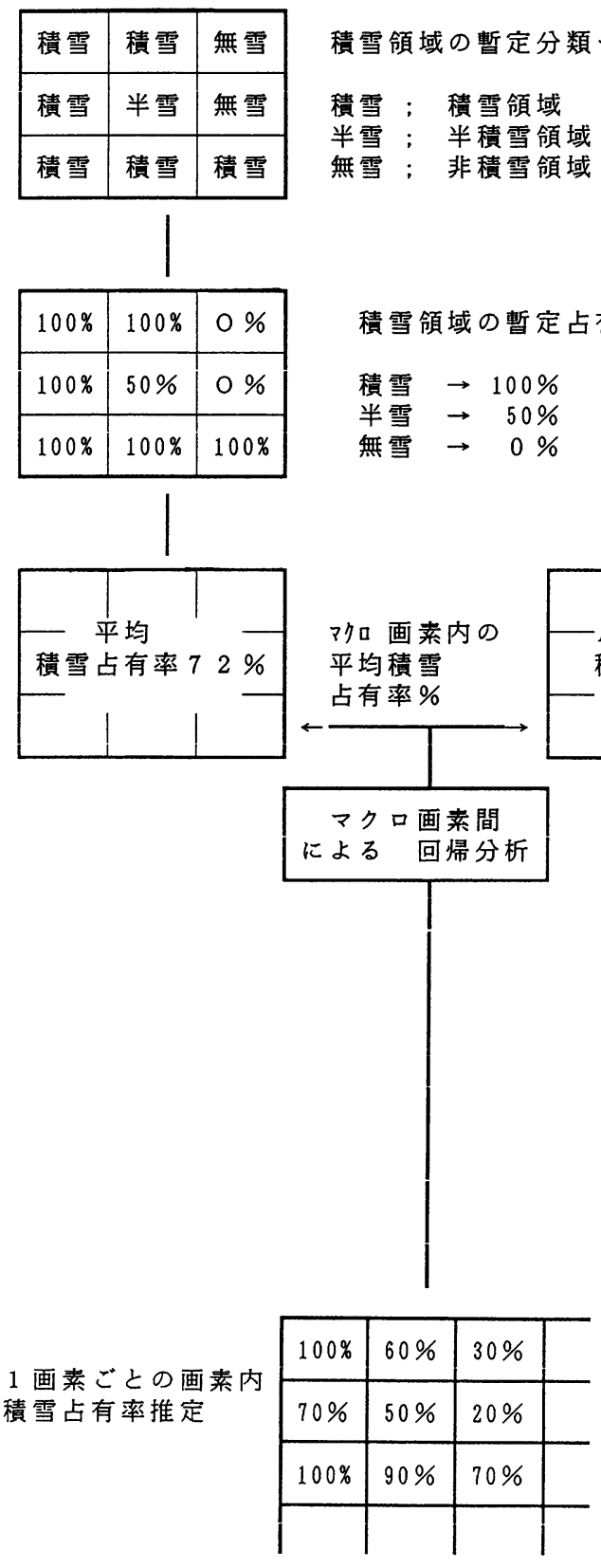

M P M による画素内積雪占有率の抽出

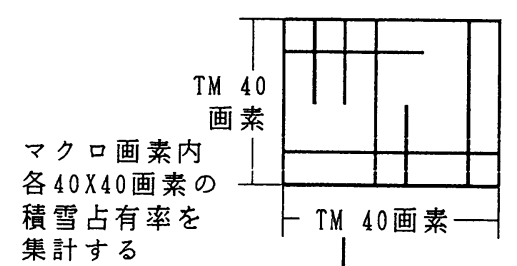

積雪判別指標または

積雪サンプルヘの

マハラノビスの距離

の平均值

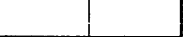

積雪占有率を

集計する

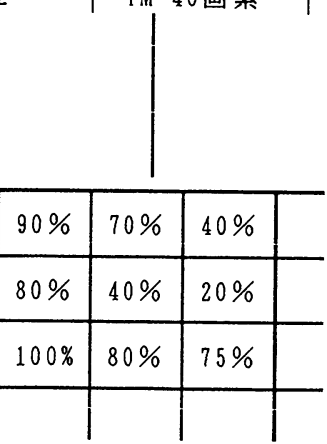

検証

T M 積雪占有率集計データ 
地被覆推定にくらべて，よりモデルを単純にし，積雪 領域と非積雪領域という 2 区分でモデルの構成が考え られる。この場合積雪領域の占有率が解れば，その補 集合である非積雪領域は必然的に求められる。つまり, 積雪領域のみに着目した場合，単項目のマクロピクセ ルモデル $(\mathrm{MPM}){ }^{18)}$ を設定することになる。単項目の 場合は，複数項目モデルに比べ，より簡潔なモデルを 組むことができ，推定が容易となる。

その内容は，困 3 に示すように，暫定分類による積 雪領域を画素内積雪占有率 $100 \%$ ，非積雪領域を $0 \%$, 半積雪領域 $50 \%$ と初期設定した。画素のマクロ化は, $3 \times 3$ 画素をマクロ画素サイズとした。マクロ画素内 積雪占有率とマクロ画素内の放射輝度の平均值との間 で単回帰モデル式(7)を設定し，回帰係数 $\mathrm{k} 1, \mathrm{k} 2$ を MPM 法により求める。

$$
\mathrm{Sa}=\mathrm{k} 1 \times \mathrm{I} \text { nsnow }+\mathrm{k} 2+\varepsilon
$$

これにより画素内積雪領域占有率(\%)Sa が推定さ れる。とは回帰誤差を示している。

\section{4. 各画素内の積雪境界位置の推定方法}

対象とする流域内において，積雪領域が融雪してい く時間的な過程に関して，以下の仮定を設定した。

「ある流域内において，積雪領域が融雪により非積 雪領域に変化する空間的および時間的な特性は，原則 的には，毎年同様のパタンを繰り返すものとする。」

これにより調査対象時点での積雪の境界位置つまり 画素内積雪位置は, 過去の当該流域での融雪の履歴状 態をモデル化すれば，推定することが可能となる。

\section{（1）過去の MSS データの集積}

図4a は, 過去の LANDSAT MSS データの T1時期 から $\mathrm{T} 2 ， \ldots \mathrm{T} n$ 時期までの積雪領域と非積雪領域の 横断面を示した模式図ものである。これらの画像デー 夕中の積雪領域 $=1$, 非積雪領域 $=0$ と考之て, 各地

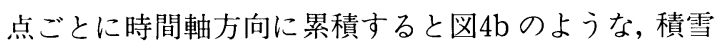
頻度データが生成される。ここで, MSS 積雪頻度と融 雪時期との関係を以下のように仮定した。

「画像中で頻度の高い所は，より雪の融けにくい領 域である確率が高く, 頻度の低い地域は，より早い時 期に融けやすい領域である。」

そこで, 積雪頻度を累積することにより，NOAAの 画素内に平面的な頻度差のパタンが細密に分布すれ

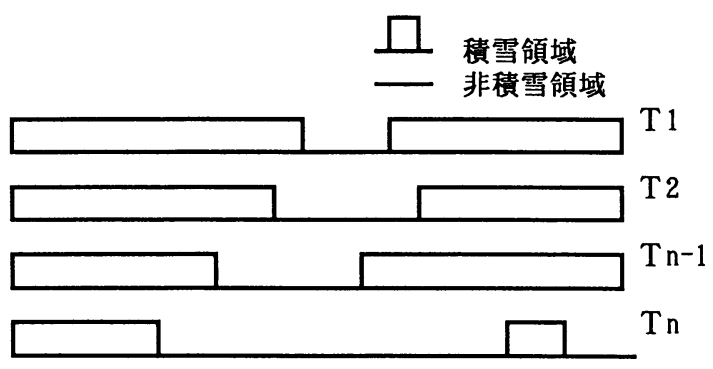

図一 4 a T1 Tn 時期の MSS 積雪領域断面

(LANDSAT MSS)

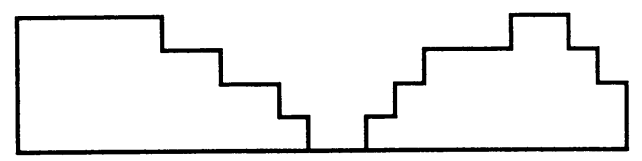

図一 4 b $\quad$ T1 Tn 時期の MSS 積雪頻度断面 (LANDSAT MSS)

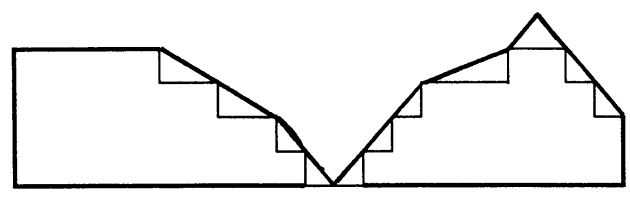

図一 4 c $\quad$ T1 〜 T 時期の MSS 積雪頻度断面 中間位置内挿処理図 (LANDSAT MSS)

ば, NOAA デー夕の画素内を融雪の発生しやすい地点 を，序列化することが可能となる。しかし，累積に用 いるデー夕の件数が少ない場合には，画素内の頻度パ タンが粗くなり，詳細な推定がおこないにくくなる。 何シーン収集すれば十分な推定精度が期待されるか は，集めるデータが融雪時期のどの段階に位置してい るかが, 大きく影響する。このため MSS データシーン 数が少ない場合は, 時期の偏りが少ないことが望まし い。本事例では，比較的バランスよく時間間隔のあい た 4 件のデー夕を用いている。

デー夕件数 4 というのは，モデル化には少ない件数 である。そこで，少ないデー夕件数で空間的な融雪パ タンを抽出しやすくするために，頻度画像デー夕の空 間的な内挿をおこなうことで，不足分を補うようにし た。図 $4 \mathrm{c}$ は段階状の頻度デー夕を内挿と先鋭化処理 した模様を図式化したものである。先鋭化は，尾根状 の領域の中央部により頻度が盛り上がるように線形の 処理を施す方式とした。 


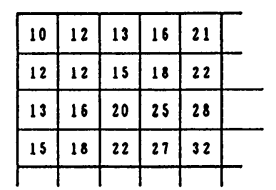

図 5 a 内挿後の積雪頻度 データ例

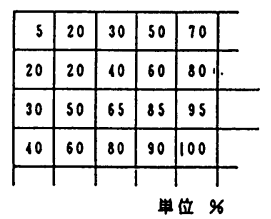

図 5 c 画素内融雪率別無 雪位置例（該当融 雪率值以下が無雪 位置)

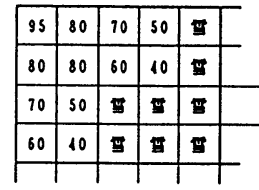

図 5 e 画素内積雪率35\% 時の場合の積雪位 置例

図 5 MSS 融雪履歴情報の説明

\section{（2）ＭSS データの画素内積雪位置のモデル化}

積雪頻度は,「対象流域において積雪から無雪状態に 移行する際の，相対的な時間順位」を示している。（図 $5 \mathrm{a}$ 参照）図 5 は仮にマクロピクセルが縦横 $4 \times 5$ の 寸法の時の模式を示している。積雪頻度の順位を NOAA データの各 1 画素内ごとに, 序列化した知識情 報 (図 $5 \mathrm{~b}$ 参照) を作成すれば，MPM による画素内占 有率との組み合わせで，各 NOAA 1 画素内ごとの積 雪分布位置が推定できることとなる。

画素内融雪位置の序列が判明すれば, 画素内の各地 点の要素は単位面積を有しているので, 画素内積雪占 有率と直接換算することが可能となる。図 $5 \mathrm{c}$ は, 画素 内の融雪率を与えて無雪地帯となる要素位置を示して いる。また図 $5 \mathrm{~d}$ は, 画素内の積雪占有率を与えて積雪 要素位置を得る知識データである。例えば画素内積雪 占有率が $35 \%$ の時 35 以下の地点は積雪領域であり, そ れ以外の地点は無雪領域と判定される。(図 $5 \mathrm{e}$ 参照) 以上のようなアルゴリズムを用いて画素内の積雪位置 を推定するモデルが設定される。この段階での推定は 画素内のみを考慮しており，第 1 次推定とする。

\section{5. 流域全体としての積雪境界位置の推定 方法}

各画素内ごとの積雪分布状態を第 4 章の手法で推定 できれば，流域内における全雪線上の平均積雪頻度值 を算出できる。この值は, 流域全体の平均的な積雪境 界位置を積雪頻度知識情報から求妨「しきい值」と なる。この值からの推定を，第 2 次推定とする。第 2 次推定では, 各画素地点は領域全体の融雪の段階の值 を基にして推定するため, 雲域が流域内の一部に存在 しても，周囲の融雪段階值を利用して，雲下領域も推 定可能となる。

具体的に流域全体の平均積雪頻度值を求めるには, まず流域内の第 1 次の積雪境界位置を集計する必要が ある。そこで，積雪境界位置のみを抽出する画像デ一 夕を作成した。これには, 第 1 次の積雪領域推定画像 の積雪・非積雪の境目の位置を，画像処理により抽出 する。処理内容は, エッジ抽出処理の一般的手法であ るラプラシアン処理をもちいることとした。ラプラシ アン処理は，具体的には，2次微分係数をもとめる空 間フィル夕操作の実行により実現でき，ラプラシアン フィルタは，(8)に示す

$$
\left(\begin{array}{rrr}
0 & 1 & 0 \\
1 & -4 & 1 \\
0 & 1 & 0
\end{array}\right)
$$

空間フィル夕処理によって実行できる。積雪境界位 置が抽出できれば，各境界位置に対応する MSS 積雪 頻度デー夕を, 参照・集計し, 流域全体の平均值つま $\eta$ 流域全体の平均的積雪境界位置を算出する。

図 5 a にはMSS 積雪頻度データの例を示してい る。図 $5 \mathrm{f}$ は, 流域全体の融雪状態が, MSS 積雪頻度 データに換算して18であった場合の模式図を示してい る。

この段階における推定を第 2 次推定とする。

\section{6. 画素内積雪境界推定手法の適用}

\section{（1） 解析諸元}

画素内積雪境界推定手法の適用を, 以下のデー夕諸 元により事例研究を試みた。

a ）積雪領域解析に用いたデータ

画素内推定用データ

$$
\text { デー夕観測 }
$$

NOAA AVHRR データ；
1984年 4 月 26 日 


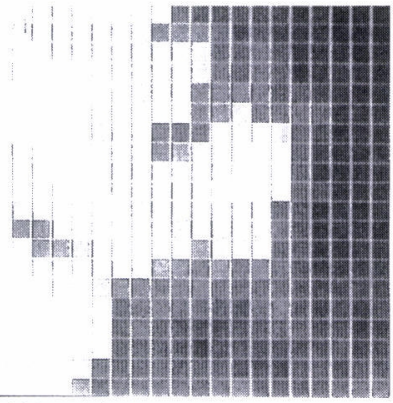

画像一 1 対象地区 NOAA - AVHRR

フォールスカラ一画像 (1984.4.26)

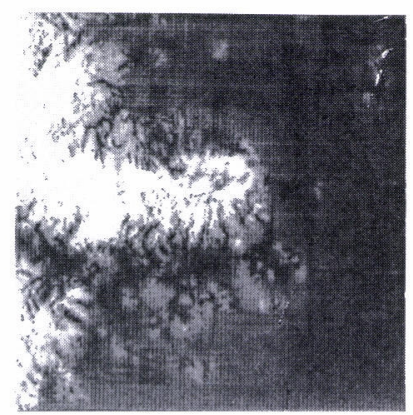

画像一 3 LANDSAT MSS 積雪頻度内扱画像

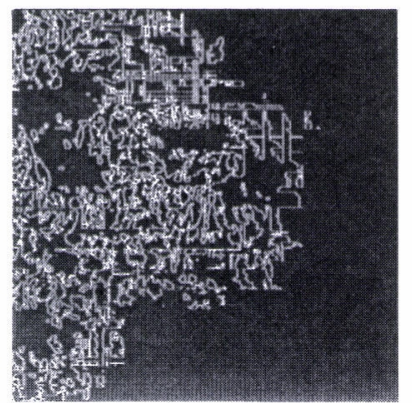

画像－51 次雪線画像の境界位置抽出画像

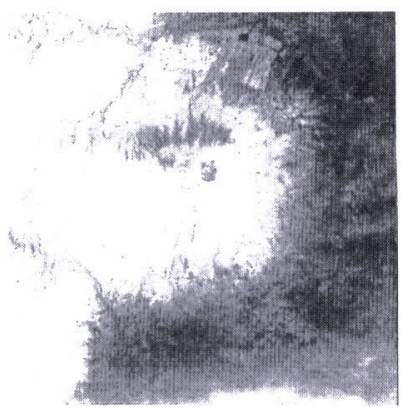

画像一 7 対象地区 LANDSAT TM

フォールスカラー画像 (1984.4.26)

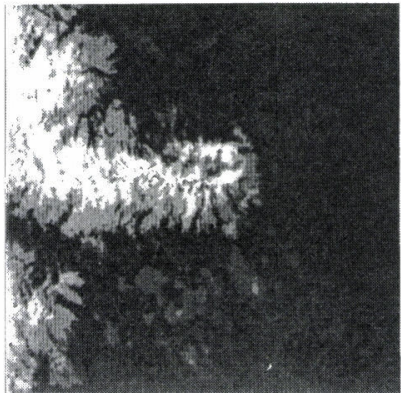

画像一2 LANDSAT 積雪頻度重ね合わせ画像 ( 4 シーン)
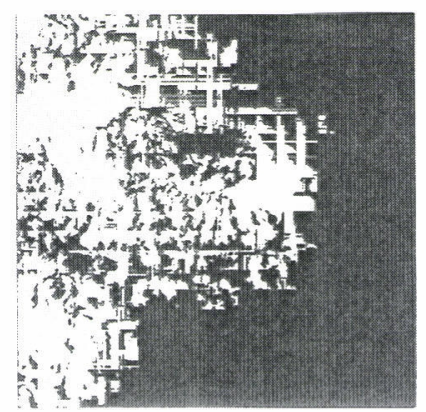

画像一 4 MSS/NOAA 画素内融雪序例による NOAA 画素内積雪境界推定画像

( 1 次雪線推定画像)

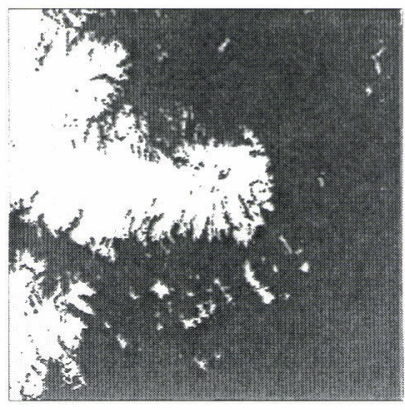

画像一 62 次雪線推定画像

1 次雪線位置の平均積雪頻度值による

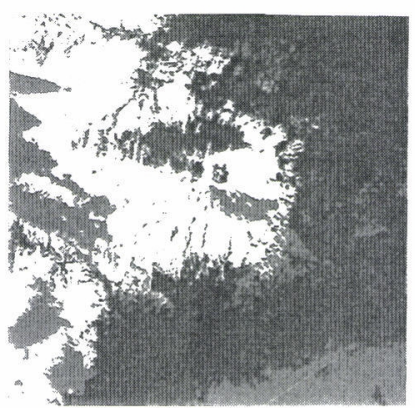

画像一 8 同日 TM データによる積雪領域の検証画 像（TM デー夕には雪が入っている） 
積雪履歴知識モデル作成用データ

LANDSAT MSS データ ;

1982年 4 月 27 日 1979年 5 月 4 日 1982年 5 月 15 日 1979年 5 月 22 日

推定結果の検証用

\section{LANDSAT TM データ;}

1984年 4 月 26 日

b ) テスト領域 岩手県岩手山山麓

北緯 $39^{\circ} 45^{\prime} 00^{\prime \prime} \sim 39^{\circ} 55^{\prime} 00^{\prime \prime}$

東緯 $140^{\circ} 52^{\prime} 30^{\prime \prime} \sim 141^{\circ} 07^{\prime} 30^{\prime \prime}$

c ）手法適用の結果

NOAA AVHRR 原画像を画像- 1 に示す。グリット 間隔はLANDSAT MSSの画素サイズに対応してお $\eta$ ，画像の空間分解能が MSS に比較して粗いことが よくわかる。

LANDSAT MSS の積雪頻度を 4 シーン分から求 めた結果を画像- 2 に示す。白い領域ほど，積雪領域で ある頻度が高いことを示している。画像-2を空間的に 内挿した画像が画像- 3 である。合成したデー夕件数が 4 シーンしかないため, 積雪頻度の低い領域では，線 形内挿の影響で線条のノイズがみられる。

NOAA デー夕の画素内積雪占有率の推定の状態は, 同日の TM データにより検証した。その結果 TM データによる集計值と NOAA デー夕による推定值の 相関係数は, $\mathrm{r}=0.907$ と良好な精度であることが, 確か められた。

MSSの融雪の履歴情報による結果を，1次推定結果 を画像- 4 に示した。2 次推定のための境界位置抽出結 果を画像- 5 に示し, 2 次推定結果を画像- 6 に示した。

また推定精度検証用の同日観測の TM 画像を画像 - 7 に示し, 検証用 TM 積雪領域抽出を画像-12に示 す。当日の TM 画像との比較検証の結果, 不一致点の 比率は $16.6 \%$ であった。（雲域は除いて集計した。）

\section{7. 画素内推定事例の考案と課題}

推定誤差が MSS の融雪履歴モデルを用しても $17 \%$ 程度発生しており，比較的精度が低いように思われる が, $3 \times 3$ 画素のウインドウで MPM を組む場合, サ ンプルに用いられる積雪占有率は，0\%，11\%，22\%， $33 \% ， 44 \% ， 56 \% ， 67 \% ， 78 \% ， 89 \% ， 100 \%$ の 種類 に限られる。このため, 推定精度もこれらの影響を受 けており， $3 \times 3$ 画素方式では, 妥当な精度が得られ
ていると考えられる。また, 準備できた MSS データの 数が 4 シーンに限られたため, 積雪頻度の低い領域で は，序列を決定するためのデー夕が不足しており，内 挿の影響をうけて、ほぼ線形に序列が配置されている。

今後, 雲域の少ない融雪期の MSS データを補充す ることができれば，システムの精度より向上させるこ とが，期待される。また， 2 次推定手法の可能性が確 認されたことにより，流域を代表させる積雪頻度のし きい值を設定すれば，流域に一部に雲域があっても， 雲下の積雪境界位置の推定が可能であることが確認さ れた。

本事例では画素を $3 \times 3$ のマクロピクセル化して扱 うために，地上寸法で $3 \mathrm{~km} \times 3 \mathrm{~km}$ 区画内の土地被覆 状態が積雪占有率 $100 \%$ の場所や $0 \%$ の場所が, サンプ ル数としてどうしても少なくなる。反面マクロピクセ ルの効用で通常では計測しにくい50\%前後の領域は数 多く採取することが可能である。回帰分析はサンプル データの直線性を利用しているので, データのレンジ が狭くなってしまうことは，好ましいことではない。

今後の改良点として,より精度の向上または安定の ためにマクロピクセルモデルの改良形として，マクロ ピクセルのサイズを可変方式にし， $1 \times 1,1 \times 2$ ， $2 \times 2$ 画素等のマクロサイズも併用した手法の検討が 必要と考えられる。

\section{参 考 文 献}

1) 武田，竹内：ランドサット経年データと積算暖度法に よる積雪分布の推定, 日本写真測量学会秋季学術講演会. 1983, 10

2 ) 武田, 竹内, 関 : NOAA デー夕を用した北海道全域の 積雪水量の推定, 日本写真測量学会年次学術講演会. 1984

3 ) 小池, 高橋, 吉野: 積雪面積情報による流域積雪水量 の推定，土木学会論文集 第375号/II-3.1985.5

4 ）力丸, 大嶋, 石田, 川口：NOAA データの画素内推定 処理による最新積雪領域抽出手法の研究, 日本写真測量 学会, 年次学術講演会論文集 (1987)

5 ) 力丸, 大嶋, 山内, 斉藤：CCD カメラを用いた積雪領 域のリアルタイム図化システムの開発, 日本写真測量学 会年次学術講演会論文集 (1988.5)

6) 力丸, 大嶋：MSS 積雪領域知識ベースによる NOAA デー夕画素内積雪境界の推定 日本写真測量学会 年次 学術講演会論文集 (1989.5)

7 ) 力丸, 向井：NOAA 赤外熱映像からの雲域抽出の研 究. 第 3 回リモートセンシングシンポジウム計測自動制 御学会 (1977)

$8)$ A. Rikimaru, T. Oshima, T. Oshima, T. Kuwabara, H. Mukai : Detail Estimation of Snow Covered Area 
from NOAA AVHRR data with New Extrac Method of Pixel Inside Information, 27th ISPRS COMMISSION VII, p416-421, Kyoto, Japan (1988)

9 ) B. J. Choudhury: Monitering Regional and Global Vegetation Using Low-Resolution Satellite Data with Special Reference to the Sahel Drought, Space and Drought Management, 39th IAF Congress, Bangalore, India, 1988

10）竹内, 富田；TM データのマルチスペクトル分類にお ける空間的情報の併用の効果, 日本リモートセンシング 学会, 第 6 回学術講演会論文集（1986年12月）

11）新井康平：TM 画像分類におけるトレーニングサン プルの抽出方法, 写真测量とリモートセンシング特集号 II, 日本写真測量学会, 1987

12）竹内, 富田: 衛星画像のスペクトル情報と空間情報を 併用した市街地の分類, Vol. 7, No. 4日本写真測量学会, 1988

13) H. M. Horwitz, R. F. Nalepka, D. Hyde, P. Morgenstern : Estimating the Proportions of Objects within a Single Resolution Element of a Multispectral Scanner, 7th ISRSE pp. 1307-1320, ERIM, 1971

14）力丸, 大嶋, 上條：スペクトル特性によるトレーニン グエリアの自動抽出手法の開発, 日本写真測量学会 年. 次学術講演論文集 (1988.5)

16）力丸, 上條, 大嶋：画素内分光合成を考慮した土地被 覆分類手法の開発, 日本写真測量学会 年次学術講演会 論文集 (1987)
17）力丸, 上條, 大嶋：画素内における分光合成モデルの 検証実験, 日本写真測量学会 秋季学術講演会論文集 (1986.10)

18）力丸, 上條, 大嶋：画素内分光情報の簡易推定手法の 開発 (原著論文), 写真測量とリモートセンシング, Vo1 27, No. 6, 日本写真測量学会 (1988)

19) Calla. o, Raju. G, Rana. S, India's first remotelysensed satellite data from BHASKARA using "SAMIR", J Inst Electron Telecommun Eng. Vol. 25 No. 8 pp. $321-324,1979$

20) Mcginnis. F, Scofield. A, Schneider. R, Berg. P, Satellites as aid to water resource managers, Proc. Am Soc Civil Eng J Water Resour Plann Manage Div, Vol. 106, No. 1, pp. 1-19, 1980

21) Hannford. F, Hall. L, Application of satellite imagery to thdrologic modeling snowmelt runoff in the southern Sierra Nevada, NASA Conf Publ No. NASA-CP- 2116 pp. 201-222, 1980

22) Tarpley J D, Schneider S R, Danaher E J, Myers G I An all-digital approach to snow mapping using geostationary Satellite data, NASA conf. Publ No. NASA-CP- 2116 pp. 267-279, 1980

23) Gird R S, Snow extent measurements from geostationary satellites using an interactive computer system, NASA Conf. Publ No. NASA-CP-2116 pp. $255^{-265,} 1980$ 